\title{
PROSES DEGRADASI LIGNIN PADA LIMBAH BATANG TEMBAKAU SEBAGAI PERSIAPAN PRODUKSI BIOETANOL
}

\section{LIGNIN DEGRADATION PROCESS ON WASTE OF TOBACCO ROD AS PREPARATION FOR BIOETHANOL PRODUCTION}

\author{
${ }^{*}$ Sri Seno Handayani ${ }^{*}$, Riki Tarnanda ${ }^{1}$, Bq. Anita Rahayu", Amrullah ${ }^{2}$ \\ ${ }^{1}$ Departement of Chemistry, University of Mataram, Jl. Majapahit no. 62 Mataram, Indonesia, \\ ${ }^{2}$ Departement of Mathematics, University of Mataram, Jl. Majapahit no. 62 Mataram, Indonesia \\ *Email: srihandayani@unram.ac.id
}

Diterima: 20 Juli 2018. Disetujui: 25 September 2018. Dipublikasikan: 30 September 2018

\begin{abstract}
Abstrak. Batang tembakau merupakan salah satu bahan lignoselulosa yang banyak tersedia, sehingga menjadikannya sebagai sumber bahan baku ideal untuk memproduksi bioetanol. Pada kajian ini dilakukan konversi bahan lignoselulosa menjadi etanol.Pada tulisan ini akan disajikan pengaruh degradasi lignin terhadap perolehan rendemen gula dan bioetanol dari batang tembakau. Hasil yang diperoleh menunjukkan bahwa degradasi lignin dengan menggunakan $8 \% \mathrm{HCl}$ dapat menurunkan lignin hingga 41,17\%. Kandungan gula hidrolisis batang tembakau tertinggi diperoleh sebesar 13,66 g / L dengan rendemen bioetanol $6.061 \%$
\end{abstract}

Kata kunci: batang tembakau, degradasi lignin, bioetanol, lignoselulosa.

\begin{abstract}
Tobacco rod is one of the lignocellulosic materials that are abundantly available, making it an ideal source of raw material for producing bioethanol. This research was conducted to convert lignocellulose material into ethanol. In this paper will be presented the effect of lignin degradationon the acquisition of sugar and bioethanol rendement from tobacco stems. The results showed that lignin degradation using $8 \% \mathrm{HCl}$ was able to degrade lignin up to $41.17 \%$. The highest sugar content of hydrolysis of tobacco rods was obtained for $13.66 \mathrm{~g} / \mathrm{L}$ with $6.061 \%$ bioethanol yield.
\end{abstract}

Keywords: tobacco rod, lignin degradation, bioethanol, lignocellulosic

\section{PENDAHULUAN}

Indonesia mengalami penurunan produksi minyak nasional yang disebabkan menurunnya secara alamiah (natural decline) cadangan minyak dunia.Namun dilain pihak, pertambahan jumlah penduduk telah meningkatkan kebutuhan sarana transportasi dan aktivitas industri yang berakibat pada peningkatan kebutuhan dan konsumsi Bahan Bakar Minyak (BBM) nasional.Pengembangan sumber energi alternatif bioetanol dapat menjadi salah satu solusi untuk mengatasi masalah krisis energi tersebut.Penggunaan bioetanol sebagai sumber energi alternatif telah mulai diterapkan di beberapanegara, seperti: Amerika Serikat, Canada, Brasil,Kolombia, Jerman, Prancis, Italia, Spanyol,Belanda, Belgia, Tiongkok, India, Thailand,Malaysia, dan Philipina [1].

Bioetanol dapat diproduksi dari sumber daya nabati yang merupakan energi terbaharukan yang bersih dan ramah lingkungan. Sumber daya nabati di Indonesia sangat berlimpah dan beragam, mulai dari yang pangan sampai dengan nonpangan Selama ini pengembangan produksi bioetanol menggunakan bahan baku yang juga merupakan sumber makanan pangan pengganti beras antara lain singkong atau ketela. Untuk menghindari persaingan pada kebutuhan pangan maka perlu dikembangkan sumber bahan baku lain yang tidak mengganggu pasokan bahan pangan.Salah satunya adalah batang tembakau yang merupakan biomassa dari limbah pertanian yang kurang memiliki nilai jual dan kurang bermanfaat namun ketersediaannya sangat melimpah di Indonesia.

Tanaman tembakau (Nicotiana tobaccum) merupakan tanaman yang mempunyai nilai ekonomis yang sangat tinggi. Dari data Statistik Perkebunan Indonesia Komoditas Tembakau tercatat bahwa pada tahun 2015 luas lahan untuk tanaman tembakau perkebunan rakyat dan perkebunan negara mencapai total 197.507 Ha dan produksi daun kering tembakau 167.425 ton [4]. Namun batang tembakau sampai saat ini masih dianggap sebagai limbah pertanian dan belum diolah secara efektif.Dengan kisaran populasi per hektar lahan adalah 22.000 pohon serta perkiraan berat batang tembakau $0,5 \mathrm{~kg}$, maka akan tersedia 2 juta ton lebih limbah batang tembakau di Indonesia.

Batang tembakau selama ini hanya dibiarkan mengering begitu saja oleh petani tanpa mengolahnya secara lebih efektif. Seringkali untuk menanggulangi limbah ini banyak petani di 
Indonesia mengatasinya dengan cara membakar batang tembakau. Hal ini tentu saja dapat membuat dampak buruk bagi lingkungan dikarenakan batang tembakau masih mengandung nikotin.Agar tidak terus mencemari lingkungan, maka perlu adanya upaya yang dapat mengolah limbah batang tembakau menjadi suatu bahan yang bermanfaat dan tidak berbahaya bagi lingkungan.Salah satu upaya yang dapat dilakukan untuk menghadapi pencemaran lingkungan ini adalah dengan memanfaatkan limbah batang tembakau menjadi bioetanol.

Batang tembakau mengandung selulosa dengan jumlah yang relatif tinggi. Menurut [10], kandungan selulosa tertinggi ditemukan pada batang tembakau yang mencapai $35-40 \%$ dari batang tembakau kering.Sedangkan menurut [8] pada batang tembakau terdapat kandungan nikotin sebesar $0,26 \%$, selulosa dan lignin berturut-turut sebesar $56,10 \%$ dan $15,11 \%$. Penelitian mengenai struktur dan komposisi batang tembakau yang dilakukan oleh[10], menyatakan bahwa materi lignoselulosa dalam batang tembakau memiliki kepadatan relatif rendah $\left(260-350 \mathrm{~kg} / \mathrm{m}^{3}\right)$ dan dengan struktur dan komposisi kimia anatomi yang mirip dengan materi kayu dari spesies kayu berdaun lebar.Dengan adanya kandungan selulosa yang tinggi menjadikan batang tembakausangat berpotensi untuk dijadikan sebagai sumber bahan baku energi alternatif bioetanol.

Pembuatan bahan-bahan lignosellulosa hingga menjadi etanol melalui empat proses utama: praperlakuan (pretreatment), hidrolisa, fermentasi, dan terakhir adalah pemisahan serta pemurnian produk etanol. Bahan-bahan lignosellulosa umumnya terdiri dari sellulosa, hemisellulosa dan lignin.Sellulosa secara alami diikat oleh hemisellulosa dan dilindungi oleh lignin.Adanya senyawa pengikat lignin inilah yang menyebabkan bahan-bahan lignosellulosa sulit untuk dihidrolisa.

Tahap praperlakuan yang merupakan tahap degradasi lignin (delignifikasi) bertujuan untuk mengurangi jumlah lignin supaya tidak mengganggu proses hidrolisis yang merupakan rangkaian pada pembuatan bioetanol. Degradasi lignin dilakukan untuk mengkondisikan bahanbahan lignoselulosa baik dari segi struktur dan ukuran dengan memecah dan menghilangkan kandungan lignin dan hemiselulosa, merusak struktur kristal dari selulosa serta meningkatkan porositas bahan. Efektivitas delignifikasi dan hidrolisis sampel dengan perlakuan kimiawi lebih optimal dibandingkan perlakuan secara fisis dan biologi [2]. Selain itu, perlakuan secara kimi, menggunakan $\mathrm{H}_{2} \mathrm{SO}_{4} \quad 1,0 \%$ bahwa penurunan kadar lignin sebesar 35,1\% pada biomasa serbuk kayusengon dan 29,3\% pada biomasa serbuk pelepahsawit $[9,16]$. Pada penelitian [5] melakukan pretreatment delignifikasi menggunakan asam sulfat encer untuk mengevaluasi penurunan kadar hemiselulosa limbah pertanian daun tebu.

Pada kajian ini dilakukan pretreatment delignifikasi batang tembakau dengan menggunakan asam klorida encer untuk mengetahui penurunan kadar lignin terurai dan pengaruhnya terhadap perolehan rendemen gula reduksi hasil hidrolisis. Efisiensi proses dievaluasi berdasarkan banyaknya gula reduksi (kadar glukosa) yang terbentuk. Kadar glukosa yang dihasilkan pada tahap hidrolisis dan kadar etanol yang dihasilkan pada akhir tahap fermentasi menjadi faktor penentu dalam mengetahui pengaruh perlakuan delignifikasi tersebut.

\section{METODOLOGI}

\section{Alat dan Bahan}

Peralatan yang digunakan pada kajian ini adalah peralatan gelas yang ada di laboratorium, gelas ukur, gelas beaker,labu Erlenmeyer, timbangan analitik, blender, hot plate, $\mathrm{pH}$ meter, $\mathrm{pH}$ stick, freezer, termometer, oven, penangas air, pipet tetes, sendok, tanur, spektrofotometer UV-Vis SHIMADZU. Alat penunjang : aluminium foil, kertas saring, dan kertas label.Bahan-bahan yang digunakan adalah limbah batang tembakau, aquades, larutan $\mathrm{HCl}$ pekat $37 \%, \mathrm{H}_{2} \mathrm{SO}_{4} 72 \%$, $\mathrm{CH}_{3} \mathrm{COOH} 2 \mathrm{~N}$, Nelson A, Nelson B, Arsenomolibdat

\section{Preparasi sampel}

Sampel limbah batang tembakau yang telah dikumpulkan disortir terlebih dahulu kemudian dipotong kecil-kecil. Selanjutnya, sampel limbah batang tembakau dikering-anginkan di bawah sinar matahari untuk mengurangi kadar airnya. Setelah kering limbah batang tembakau dihaluskan menggunakan blender.

\section{Pengukuran Kadar Air}

Kadar air ditetapkan dengan metode oven. Sebanyak 1 gram sampel ditimbang lalu dioven selama 1 jam dengan suhu $105{ }^{\circ} \mathrm{C}$. Didinginkan dalam desikator selama 15 menit.Sampel yang sudah kering lalu ditimbang.Pengeringan dilakukan berulang-ulang hingga didapat berat konstan.

\section{Analisis kadar abu}

Sampel ditimbang sebanyak 5 gram pada cawan porselin yang sebelumnya telah dipanaskan dan diketahui berat keringnya.Sampel dimasukkan dalam tanur dan dipanaskan sampai suhu $575{ }^{\circ} \mathrm{C}$ selama 4 jam.Kemudian didinginkan dalam desikator dan ditimbang sampai suhunya tetap. 


\section{Analisis Kadar Selulosa}

Sebanyak 3 gram sampel kering dimasukkan ke dalam gelas kimia $250 \mathrm{ml}$. Sampel dibasakan dengan $15 \mathrm{ml} \mathrm{NaOH} 17,5 \%$ dan dimaserasi selama 1 menit, lalu ditambahkan $10 \mathrm{ml} \mathrm{NaOH} 17,5 \%$, diaduk dan dibiarkan selama 3 menit. Kemudian ditambahkan kembali $3 \times 10 \mathrm{ml} \mathrm{NaOH} 17,5 \%$ setiap 2,$5 ; 5 ; 7,5$ menit dan dibiarkan selama 30 menit. Setelah itu ditambahkan $100 \mathrm{ml}$ aquades dan dibiarkan selama 30 menit, lalu campuran disaring dan endapan dicuci dengan $5 \times 50 \mathrm{ml}$ aquades. Kertas saring yang berisi endapan dipindahkan ke gelas kimia dan dicuci kembali dengan $400 \mathrm{ml}$ aquades, ditambahkan $10 \mathrm{ml}$ asam asetat glasial $2 \mathrm{~N}$ dan diaduk selama 5 menit. Endapan disaring dan dikeringkan dalam oven dengan suhu $105{ }^{0} \mathrm{C}$, kemudian didinginkan dalam desikator dan ditimbang hingga berat konstan

\section{Delignifikasi}

Ditimbang sebanyak 12 gram sampel, masingmasing dimasukkan dalam erlenmeyer $250 \mathrm{ml}$ dan diberi label. Selanjutnya ditambahkan larutan larutan $\mathrm{HCl}$ dengan variasi konsentrasi $1 \% ; 2 \%$; $3 \% ; 4 \% ; 5 \% ; 6 \% ; 7 \%$ dan $8 \%$ dipanaskan dalam penangas air dengan waktu 60 menit pada suhu $70^{\circ} \mathrm{C}$. Selanjutnya sampel disaring dan dicuci dengan aquadest berlebih, lalu dikeringkan dalam oven selama 2-3 jam pada suhu $100{ }^{\circ} \mathrm{C}$. Selanjutnya sampel didinginkan pada suhu kamar. Setelah kering, sebagian sampel hasil delignifikasi diuji kadar ligninnya dengan metode gravimetri.

\section{Analisis Kadar Lignin}

Sampel ditimbang sebanyak 2 gram kemudian dimasukkan dalam gelas kimia dan ditambahkan sedikit demi sedikit $\mathrm{H}_{2} \mathrm{SO}_{4} 72 \%$ sebanyak $40 \mathrm{ml}$ sambil diaduk sampai semua sampel terendam dan terdispersi. Setelah terdispersi, gelas kimia ditutup dan dijaga pada temperatur $20^{\circ} \mathrm{C}$ selama 2 jam kemudian ditambahkan $400 \mathrm{~mL}$ aquades ke dalam gelas kimia, larutan didihkan selama 4 jam dalam gelas kimia, kemudian didiamkan sampai endapan lignin mengendap kemudian endapan lignin disaring untuk mendapatkan lignin. Lignin dicuci dengan air panas lalu dikeringkan dalam oven dan setelah kering didinginkan di dalam desikator dan ditimbang tiap 15 menit sampai berat lignin konstan.

\section{Hidrolisis}

Batang tembakau yang sudah didelignifikasi, diambil sebanyak 10 gr, kemudian ditambahkan aquades $80 \mathrm{ml}$ dan direfluks selama 3 jam.Sampel didinginkan dan disaring hingga didapatkan filtratnya. Filtrat yang didapatkan ditambahkan
$\mathrm{HCl} 2 \%$ dengan perbandingan volume $(1: 1,5)$ dalam wadah erlenmeyer yang dilengkapi dengan magnetic stirer. Proses pemanasan dilakukan di atas hot plate pada suhu $80^{\circ} \mathrm{C}$ selama 1 jam [7].

\section{Analisis kadar glukosa}

Kadar glukosa hasil hidrolisis diukur dengan metode Nelson Somogy dengan mempersiapkan kurva standar terlebih dahulu. Kurva standar diperoleh dari larutan glukosa standar dengan konsentrasi masing-masing $10 \mathrm{ppm}, 30 \mathrm{ppm}, 50$ ppm, dan 70 ppm yang digunakan pada pengukuran dengan menggunakan spektrofotometri UV vis. Sampel uji kadar glukosal $\mathrm{ml}$ dimasukkan ke dalam tabung reaksi yang bersih dan kering. Setelah itu ditambahkan $1 \mathrm{ml}$ pereaksi Nelson A dan Nelson B. selanjutkan diperlakukan seperti pada penyiapan kurva standar.Jumlah gula reduksi dapat ditentukan berdasarkan absorbansi larutan sampel, lalu dimasukkan melalui persamaan regresi atau kurva standar larutan glukosa.

\section{HASIL DAN PEMBAHASAN}

Kajian ini diawali dengan uji pendahuluan pada sampel batang tembakau berupa analisis kadar air, analisis kadar selulosa, analisis kadar lignin dan analisis kadar abu. Sampel batang tembakau diambil dari perkebunan rakyat di daerah Lombok Utara-Nusa Tenggara Barat. Dari hasil uji pendahuluan diperoleh kadar selulosa batang tembakau cukup besar yaitu sebesar 50\% dengan kadar lignin 17\%.

\section{Delignifikasi}

Delignifikasi batang tembakau dilakukan menggunakan asam klorida encer dengan variasi konsentrasi $2,0 \%, 4,0 \%, 6,0 \%$, dan $8,0 \%(\mathrm{v} / \mathrm{v})$ pada suhu $70^{\circ} \mathrm{C}$ selama 1 jam. Hubungan kadar lignin teruran dengan konsentasi $\mathrm{HCl}$ dapat dilhat pada Gambar 1.

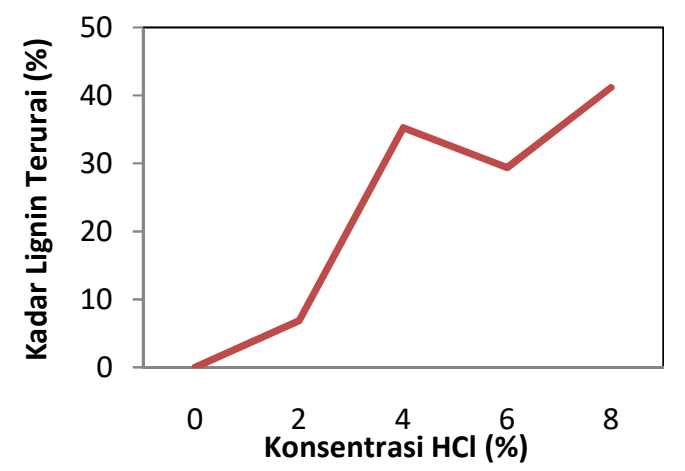

Gambar 1. Pengaruh konsentrasi $\mathrm{HCl}$ terhadap persen Lignin Terurai 


\section{Proses Hidrolisis}

Proses hidrolisis dilakukan menggunakan asam klorida dengan konsentrasi rendah. Hal ini dikarenakan jika hidrolisis menggunakan asam dengan konsentrasi tinggi akan mempercepat prosesnya, namun dapat menurunkan jumlah hasil gula reduksi. Hal ini dikarenakan sifat dari glukosa yang mudah terurai. Jika hidrolisis menggunakan asam dengan konsentrasi rendah, proses hidrolisis berlangsung lama namun dapat mengurangi penguraian glukosa oleh asam (Olivia, 2004). Hidrolisis lignoselulosa dengan asam encer adalah yang paling umum diaplikasikan untuk mendapatkan gula sebagai bahan baku fermentasi menjadi bioetanol. Umumnya, hidrolisis asam encer menggunakan asam mineral seperti H2SO4dan $\mathrm{HCl}$, pada suhu antara 120-200oC [11]. Hidrolisis kimiawi cenderung memutuskan ikatan glikosida secara acak. Terjadinya pemutusan ikatan ini berpengaruh terhadap kadar glukosa yang diperoleh. Proses hidrolisis berbahan lignoselulosa yang telah dilakukan antara lain hidrolisis serbuk gergaji menggunakan larutan $\mathrm{H} 2 \mathrm{SO} 40,5 \%$ mendapatkan gula dengan kadar $11,53 \mathrm{mg} / \mathrm{ml}$ [13]. Hidrolisis sampah buah dan sayur menggunakan larutan $\mathrm{H} 2 \mathrm{SO} 4 \quad 0,25 \%$ menghasilkan gula 17,92 mg/ml [15].

Pada kajian ini, dilakukan proses hidrolisis menggunakan larutan $\mathrm{HCl} 2 \%$ yang dipanaskan dengan refluks selama 1 jam dengan suhu $80{ }^{\circ} \mathrm{C}$. Penggunaan suhu yang terlalu tinggi pada saat proses hidrolisis akan mengakibatkan glukosa terdegradasi dan menghasilkan furfural sehingga larutan akan menjadi lebih gelap atau warna larutan hasil hidrolisis akan semakin tua sehingga dapat menghambat proses selanjutnya. Proses hidrolisis disini menghasilkan larutan berwarna kuning sedikit bening yang menunjukkan larutan mengandung glukosa.

\section{Uji Kadar Glukosa}

Gula reduksi hasil hidrolisis asam dapat dianalisis secara kualitatif untuk mengidentifikasi apakah sampel mengandung gula reduksi atau tidakdan secara kuantitatif untuk menentukan kadar gula reduksiyang terbentuk. Untuk maksud tersebut,analisis gula reduksi secara kualitatif dapat dilakukan denganujiBenedict, uji Fehling, uji Barfoed, uji Tollens, dan uji Molisch.Analisis gula reduksi secara kuantitatif dapat dilakukan dengan berbagai cara, antara lain dengan metode Luff Schoorl, Nelson-Somogyi dan metode DNS.

Pada kajian ini kadar glukosa hasil hidrolisis batang tembakau diukur dengan metode NelsonSomogy. Prinsip kerja metode ini adalah kuprioksida akan bereaksi menjadi kuprooksida
$\left(\mathrm{Cu}_{2} \mathrm{O}\right)$ atau karena adanya gula reduksi (endapan merah bata). Jumlah endapan merah bata sebanding dengan jumlah gula reduksi.Larutan hasil hidrolisis ditambahkan pereaksi nelson A dan Nelson B kemudian dipanaskan di air mendidih selama 20 menit dengan tujuan untuk mempercepat proses reduksi kuprioksida menjadi kuprooksida $\left(\mathrm{Cu}_{2} \mathrm{O}\right)$. Selanjutnya larutan didinginkan sampai suhunya $25^{\circ} \mathrm{C}$ supaya reaksi berjalan stabil, karena apabila terlalu panas dapat menyebabkan ada komponen senyawa yang rusak atau habis menguap. Kemudian ditambahkan kembali dengan reagen arsenomolibdat agar bisa bereaksi dengan endapan kuprooksida $\left(\mathrm{Cu}_{2} \mathrm{O}\right)$ yang menghasilkan larutan berwarna biru. Adapun reaksi yang terjadi :

Gulapereduksi $+2 \mathrm{Cu}^{2+} \longrightarrow \mathrm{Cu}_{2} \mathrm{O}_{(\mathrm{s})}$

Pada peristiwa ini kuprooksida akan mereduksi kembali arsenomolibdat menjadi molibdene blue yang berwarna biru. Larutan tersebut kemudian digojog hingga endapan merah bata hilang secara perlahan dan ditambahkan dengan aquades yang bertujuan untuk mengurangi kepekatan larutan sehingga dapat terbaca absorbansinya.Selanjutnya, sampel diuji dengan UV-Vis pada panjang gelombang $540 \mathrm{~nm}$. Selanjutnya nilai absrorbansi sampel yang didapatkan dari hasil analisis spektrofotometer UV-Vis dimasukkan ke dalam persamaan regresi kurva standar untuk penentuan kadar glukosanya.

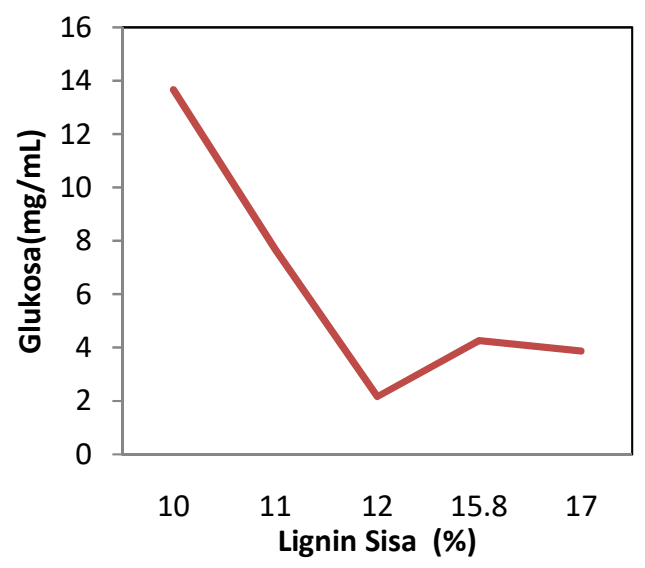

Gambar 2. Kadar glukosa hasil hidrolisis sampel serbuk batang tembakau

Berdasarkan data pada tabel di atas, dapat dilihat pengaruh lignin sisa terhadap kadar gula reduksi yang dihasilkan dari hasil hidrolisis selulosa batang tembakau. Dimana pada lignin sisa $10 \%$ didapatkan kadar gula reduksi yang cukup tinggi yaitu $13,66 \mathrm{~g} / \mathrm{L}$ dengan total dua kali pengulangan. Sedangkan pada lignin sisa $11 \%$, diperoleh total gula pereduksi sebesar 7,66 g/L. Hal ini menunjukkan semakin rendah lignin sisa yang dihasilkan maka semakin besar pula kadar gula 
reduksi yang diperoleh. Konsentrasi lignin yang rendah dalam bahan inilah yang merupakan faktor utama dalam meningkatkan derajat hidrolisis $[6,12]$. Hasil ini membuktikan bahwa kehilangan lignin setelah delignifikasi merupakan faktor kunci pendorong untuk memproduksi gula reduksi yang tinggi.

\section{Proses Fermentasi}

Proses selanjutnya adalah fermentasi. Dalam proses ini terjadi perombakan molekul-molekul glukosa menjadi alkohol dan $\mathrm{CO}_{2}$ dengan bantuan mikroba. Prinsip dasar fermentasi adalah mengaktifkan kegiatan mikroba tertentu untuk tujuan mengubah sifat bahan, agar dapat dihasilkan sesuatu yang bermanfaat.

Pada kajian ini dilakukan dua tahap fermentasi yaitu pada 24 jam pertama dilakukan proses agitasi menggunakan water bath shaker pada suhu $25^{\circ} \mathrm{C}$ $30^{\circ} \mathrm{C}$ dengan tujuan untuk meningkatkan kontak antara mikroba dengan nutrisi yang ditambahkan kedalam substrat sehingga tersuspensi dengan homogen. Proses agitasi juga bertujuan untuk mempermudah difusi oksigen sehingga kadar oksigen terlarut dalam media cukup untuk mendukung pertumbuhan sel secara aerobik.

$$
\text { Saccharomyces cereviceae mampu }
$$
meghasilkan enzim zimase dan intervase. Enzim zimase berfungsi memecahkan selulosa yang masih terdapat saat proses hidrolisis untuk mengubah menjadi glukosa, sedangkan enzim intervase yang mengubah glukosa menjadi alkohol dengan proses fermentasi [14].

Setelah dilakukan proses agitasi selama 24 jam, proses fermentasi dilanjutkan dengan penyimpanan didalam ruang tertutup pada suhu kamar selam 6 hari dan suhu dipertahankan tetap $26-30^{\circ} \mathrm{C}$. Dalam proses fermentasi terjadi reaksi pembentukan alkohol seperti yang ditunjukkan persamaan berikut:

$\begin{array}{ll}\mathrm{C}_{2} \mathrm{H}_{12} \mathrm{O}_{6} \\ \text { Glukosa } & 2 \mathrm{CH}_{3} \mathrm{CH}_{2} \mathrm{OH}+2 \mathrm{CO}_{2} \\ \text { etanol }\end{array}$

Gambar 3.Reaksi pembentukan etanol

Bioetanol yang dihasilkan dari proses fermentasi ini masih mengandung gas $\mathrm{CO}_{2}$. Proses pembersihan (washing) $\mathrm{CO}_{2}$ dapat dilakukan dengan menyaring bioetanol yang terikat oleh $\mathrm{CO}_{2}$, sehingga diperoleh bioetanol yang bersih dari gas $\mathrm{CO}_{2}$

\section{Destilasi}

Pemisahkan bioetanol dari produk-produk lainnya dilakukan dengan proses destilasi. Destilasi merupakan metode pemisahan berdasarkan perbedaan titik didih. Proses ini dilakukan untuk mengambil bioetanol dari hasil fermentasi. Bioetanol mempunyai titik didih lebih rendah daripada air, yaitu $78,4{ }^{\circ} \mathrm{C}$, sedangkan air $100{ }^{\circ} \mathrm{C}$ pada kondisi standar sehingga destilasi dilakukan pada suhu sekitar $70-80{ }^{\circ} \mathrm{C}$. Kadar etanol meningkat seiring dengan kenaikkan persentase kadar gula. Menurut [3]kadar glukosa yang optimum untuk menghasilkan kadar etanol adalah $14-28 \%$

\section{Analisis GC-MS}

Untuk mengetahui hasil destilasi yang terbentuk merupakan etanol maka dilakukan pengujian sampel etanol hasil destilasi dengan menggunakan alat GC-MS. Standar yang digunakan yaitu etanol murni dan bioetanol hasil fermentasi kemudian diinjeksikan kedalam kolom kromatogafi gas. Kromatogram hasil GC ditunjukkan pada Gambar berikut:

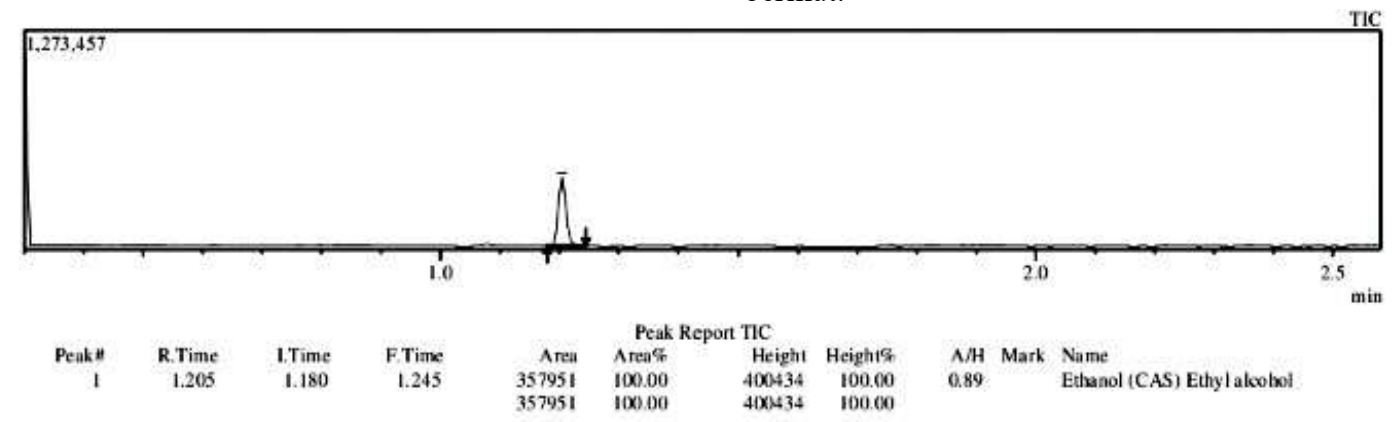

Gambar 3. Kromatogram hasil GC

Dari hasil analisis GC-MS diatas, dapat dilihat bahwa etanol adalah produk utama dalam pembuatan bioetanol dari proses fermentasi hidrolisat batang tembakau menggunakan bakteri Saccharomyces cereviceae dengan luas area sebesar 100 dan persentase kemurnian sebesar $100 \%$. Pada analisis MS, senyawa yang terdeteksi oleh GC akan diionisasi kembali oleh MS. Dengan adanya serangan elektron yang membentuk fragmen-fragmen, oleh MS akan terbaca menjadi puncak-puncak fragmen molekul bermuatan yang 
dapat diukur dengan rasio per muatan $(\mathrm{m} / \mathrm{z})$ yang dimiliki.

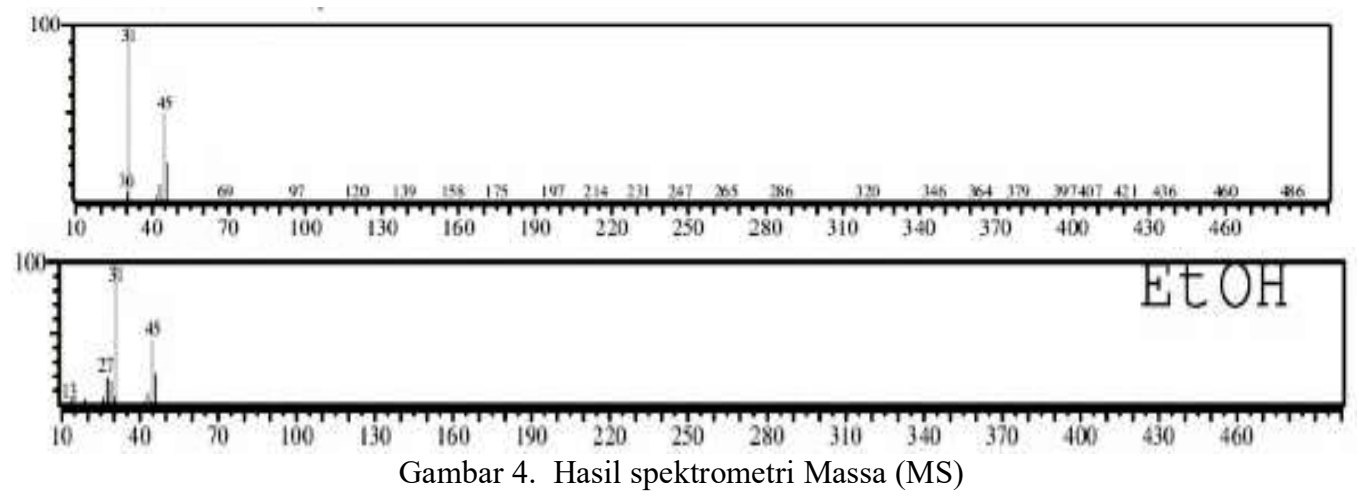

Berdasarkan pola fragmentasi pada spektroskopi massa tersebut, diketahui senyawa puncak dasar ion molekul $\left(\mathrm{M}^{+}\right)$dengan $\mathrm{m} / \mathrm{z}=45$ menunjukkan bahwa senyawa tersebut adalah etanol.

\section{KESIMPULAN}

Berdasar hasil kajian ini diperoleh kesimpulan bahwa

1.Kandungan selulosa pada limbah batang tembakau mencapai 50\% sehingga berpotensi untuk dijadikan bahan baku bioetanol.

2. Kandungan lignin dalam batang tembakau yang cukup tinggi yaitu mencapai $17 \%$ mengharuskan tahapan proses konversi batang tembakau menjadi bioetanol melewati praperlakuan delignifikasi

3. Degradasi lignin tertinggi diperoleh pada perlakuan delignifikasi dengan $\mathrm{HCl} 8 \%$ yang menghasilkan kadar ligin terurai sebesar $41,17 \%$

4. Kehilangan lignin setelah delignifikasi merupakan faktor pendorong untuk memproduksi gula reduksi yang tinggi. Kadar gula reduksi hasil hidrolisis batang tembakau tertinggi diperoleh sebesar13,66 g/L

\section{UCAPAN TERIMAKASIH}

Ucapan terima kasihdisampaikan kepadaProgram Hibah Produk Terapan Ristek DIKTI" 2017, Kementerian Riset, Teknologi dan Pendidika Tinggi yang telah mendanai kajian ini.

\section{DAFTAR PUSTAKA}

[1] Walter, A., F. Rosillo-Calle, P. Dolzan, E. Pracente, and K.B. da Cunha. (2008). Perspective on Fuel Ethanol Consumption and Trade.Biomass and Bioenergy, 32, 730748
[2] Agustini dan Efiyanti, 2015. Pengaruh perlakuan delegnifikasi terhadap hidrolisis selulosa, Journal of Forest Product Research, 33 (1): 69-80.

[3] Budiyanto, M. A. K. 2003. Mikrobiologi Terapan . Malang: UMM Press.

[4] DirJen Perkebunan, Statistik Perkebunan Indonesia Komoditas Tembakau 2014 - 2016, Direktorat Jenderal Perkebunan, Jakarta, 2015.

[5] Jimmy, Poespowati, T., Noertjahjono, S. Prosiding Seminar Nasional Kimia, ISBN: 978-602-0951-05-8 Jurusan Kimia FMIPA Universitas Negeri Surabaya, 3-4 Oktober 2015

Jumino, 2013, Konsep pengelohan barang tembakau menjadi bubur selulosa dan uji speifikasinya sebagai bahan kertas

[6] Kim, J.S., Y.Y. Lee, and T.H. Kim. 2016. A review on alkaline pretreatment technology for bioconversion of lignocellulosic biomass. Bioresource Technology 199: 42-48.

[7] Kusuma, Indra.D. P. 2012.Optimasi Pembuatan Bioetanol dari Limbah Tahu.Mataram. UNRAM press.

[8] Liu, Y., Dong, J., Liu, G., Yang, H., Liu, W., Wang, L., Kong, C., Zheng, D., Yang, J., Deng, L., and Wang, S. 2015. Co-Digestion of Tobacco Waste With Different Biocultural Biomass Feedstocks and The Inhibition of Tobacco Viruses by Anaerobic Digestion. Bioresour. Technol. 189, 210-216.

[9] Mutreja, R., Das, D., Goyal, D., and Goyal, A., (2011), Bioconversion of Agricultural Waste to Ethanol by SSF Using Recombinant Cellulase from Clostridium thermocellum, Enzyme Research, Vol. 2011, Article ID 340279, pp. 1-6. 
[10] Pesevski, M.D., Iliev, B.M., Zivkovic, D.J., Popovska, V.T.J.,Srbinoska, M.A., Filiposki,B. Possibilities for utilization of tobacco stems for production of energetic briquettes. Journal of Agricultural Sciences.V.55,n.1, 45-54, 2010.

[11] Taherzadeh, M.J., dan Keikhosro Karimi. 2007. Pretreatment of Lignocellulosic Wastes to Improve Ethanol and Biogas Production: A Review International Journal of Molecular Science. Isfahan : Department of Chemical Engineering.

[12] Sun, S., S. Sun, X. Cao, and R. Sun. 2016. The role of pretreatment in improving the enzymatic hydrolysis of lignocellulosic materials. Bioresource Technology 199: 4958
[13] Sediawan, W. B., Megawati, Millati, R., and Syamsiah, S., 2007, "Hydrolysis of Lignocellulosic Waste for Ethanol Production", International Biofuel Conference, Bali

[14] Afriani, Suryono \& H. Lukman. 2011. Karakteristik Dadih Susu Sapi Hasil Fermentasi Beberapa Starter Bakteri Asam Laktat yang Diisolasi Dari Dadih Asal Kabupaten Kerinci. Agrinak.1 (1): 36-42

[15] Wicakso, D.R. dan Mirwan, A., 2008, "Hidrolisis Karbohidrat Dari Sampah Sayur dan Buah Dengan Katalisator H2SO4 Encer Sebagai Bahan Baku Bioetanol”, Jurnal InfoTeknik, 2008.

[16] Handayani, S. S., Hadi, S., \& Patmala, H. (2016). Fermentasi Glukosa Hasil Hidrolisis Buah Kumbi untuk Bahan Baku Bioetanol. Jurnal Pijar Mipa,11(1). 